\title{
Biotic and abiotic parameters at a subtropical fee-fishing farm
}

\author{
Rodrigo Ney Millan* and Lúcia Helena Sipaúba-Tavares
}

Limnology and Plankton Production Laboratory, Aquaculture Center, Universidade Estadual Paulista-UNESP, Postal Code 14884-900, Jaboticabal SP Brazil.

* Corresponding author: rodrigomillan@yahoo.com.br

Received: 28/11/2012

Accepted: 07/01/2014

\begin{abstract}
Biotic and abiotic parameters in a subtropical fee-fishing farm

This study was conducted to evaluate the plankton communities and water quality at a fee-fishing farm over a 1-year period. Samples for the determination of biotic and abiotic variables were collected monthly during the study year. Water samples were collected at 7 sampling sites: inlet water, wetland, fishponds ( 3 sites), soil filter system and outlet water. The temperature, dissolved oxygen, $\mathrm{pH}$ and nutrients were measured. A similarity analysis for plankton densities and nutrients detected 4 groups of sites. The outlet water site differed markedly from the other sites. Higher nitrate and nitrite concentrations were observed at the inlet water and wetland sites in association with species belonging to the Bacillariophyceae, Cyanobacteria and Zygnemaphyceae. Fishpond sites 2 and 3 were associated with species belonging to the Chlorophyceae and with variables such as temperature, dissolved oxygen and $\mathrm{pH}$. Zooplankton communities were most distinctive in the soil filter system. Rotifers were the most representative group among the zooplankton communities. The results demonstrated that plankton communities and abiotic variables were affected by water flow and by animals in the neighbouring areas. The soil filter system at the effluent of the fee-fishing farm was found to be an important tool, suitable for adoption in aquaculture systems to improve outlet water quality.
\end{abstract}

Key words: Phytoplankton, zooplankton, limnology, physical and chemical parameters, fish-ponds.

\section{RESUMEN}

\section{Parámetros bióticos y abióticos en estanques de pesca subtropicales}

El presente estudio ha realizado el seguimiento de la comunidad planctónica y la calidad del agua en un sistema de "Estanques de Pesca" durante un año. Las muestras para la cuantificación de las variables bióticas y abióticas se tomaron de forma mensual durante un año en siete puntos: entrada del agua al sistema, humedal, tres estanques de pesca, sistema de filtración y salida del agua del sistema. Se midieron la temperatura, oxígeno disuelto, pH y concentraciones de nutrientes. El análisis de similitud para la densidad planctónica y las concentraciones de nutrientes detectó cuatro grupos. La salida del agua fue considerablemente diferente de los otros puntos. En los puntos de entrada del agua y humedal se observaron cantidades altas de nitrato y nitrito, y aparecieron especies de los grupos Bacillariophyceae, Cyanobacteria y Zygnemaphyceae. Los estanques de peces $\left(\begin{array}{l}2 \\ \text { y }\end{array}\right.$ 3) se asociaron con la dominancia de especies de Chlorophyceae, así como con variables como la temperatura, oxígeno disuelto y $\mathrm{pH}$. La comunidad zooplanctónica en el sistema de filtrado fue la que presentó mayores diferencias. Rotifera fue el grupo más representativo de la comunidad zooplanctónica. Los resultados demuestran que la comunidad planctónica y las variables abióticas se vieron afectadas por el flujo continuo del agua y por los animales domésticos presentes alrededor del ambiente estudiado. El filtro del suelo situado a la salida del sistema demostró ser una importante herramienta en la mejora de la calidad del agua del efluente, siendo recomendable su adopción en sistemas de acuicultura.

Palabras clave: Fitoplancton, zooplancton, limnología, parámetros físicos y químicos, estanques de pesca. 


\section{INTRODUCTION}

Anglers and farmers have found that the use of lakes/ponds on a private fee basis represents an attractive outdoor recreation alternative. Such sites are termed fee-fishing farms. Fee-fishing was introduced in Brazil in the 1980s to improve land use and increase the sales of fish, and this recreational resource has attracted the attention of many farmers. Fee-fishing customers pay a daily fee or a fee based on the weight of the fish caught. However, management for fee-fishing may result in water of apparently low quality and may encourage the growth of undesirable planktonic species. In places where public fishing areas are experiencing crowding because of population growth and urban expansion, private landowners are developing private ponds to accommodate demands for fishing opportunities (Schuett et al., 2007).

The successful operation of a fee-fishing farm requires that an equilibrium be maintained between water dynamics and quality (biotic and abiotic variables) and management. A fee-fishing farm provides a manageable human scale on which the impact of local actions can be observed in a short space of time. Management for fee-fishing may interfere directly with water and the diversity of plankton communities. Recreational fishing in all types of water bodies remains popular nationwide and requires good resource quality to be successful, but any change may contribute to a decrease in the chemical and biological quality of the water.

The relationship between external nutrient loading and the nutrient concentration in the pond depends on processes occurring within the pond and thus on physical, chemical and biological parameters. Initial changes in aquatic communities due to increasing eutrophication begin with phytoplankton succession, including species composition and abundance (Rahmati et al., 2011).

The composition of plankton communities in shallow ponds is affected by environmental factors such as nutrients, $\mathrm{pH}$, temperature, management, fertilisers, morphometry, trophic status and light (Antón-Pardo \& Armengol, 2010; Rahmati et al., 2011). In shallow ponds, the structural characteristics of the plankton community serve as indicators of the water quality parameters and of the possible success or failure of a culture system. Water quality is manipulated through the application of fertilisers to facilitate the successful colonization and abundance of plankton communities. These measures increase the populations of copepods and cladocerans in the fishponds (Ssanyu et al., 2011). The fee-fishing ponds are suitable for studies of the influence of natural processes and anthropogenic activities (management) on plankton communities.

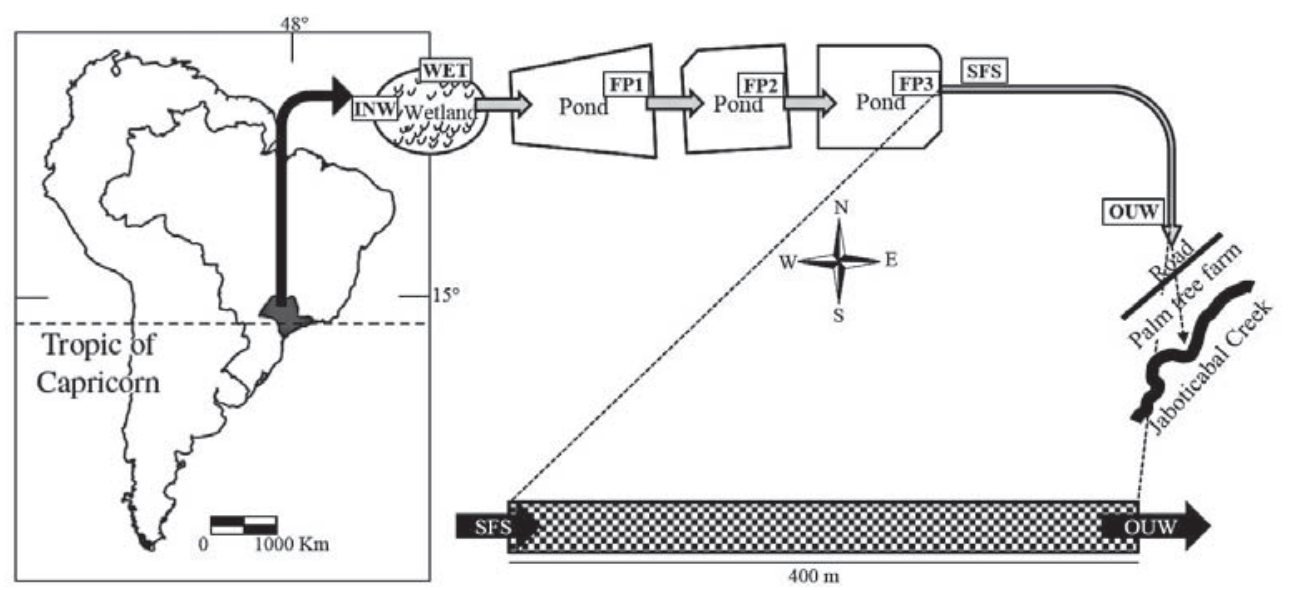

Figure 1. Cross-section of fee-fishing farm with sampling sites. INW = inlet water; WET = wetland; FP1, FP2 and FP3 = fishponds; SFS = soil filter system; OUW = outlet water. Representación esquemática de los puntos de muestreo. INW = entrada de agua, WET = Humedal, FP1, FP2 y FP3 = estanques de peces, SFS = Sistema de filtración, OUW = salida de agua. 
The management measures implemented on fee-fishing farms, in conjunction with the high external loading of nutrients, have stimulated outbreaks of phytoplankton (e.g., cyanobacteria), and consequently the appearance of water blooms. (Pokorný \& Hauser, 2002). On feefishing farms with high levels of organic compounds and fertilizers, reduced water quality may produce significant economic liabilities, including the loss of fish stocks or the production of low-quality fish (Matsuzaki et al., 2004).

Although the recreational opportunities offered by fee-fishing farms represent significant societal value, the management of these systems affects the water and requires attention. The present investigation was conducted to evaluate the plankton communities in relation to the continuous water flow and the application of biological treatments to the inlet water (wetland) and water outlet (soil filter system) of a fee-fishing farm.

\section{MATERIALS AND METHODS}

\section{Area and sampling sites}

This study was performed on a fee-fishing farm in northwestern São Paulo State, Brazil $\left(21^{\circ} 15^{\prime} \mathrm{S}\right.$; $\left.48^{\circ} 18^{\prime} \mathrm{W}\right)$, mean altitude $605 \mathrm{~m}$. The fee-fishing farm comprises 3 earthen ponds with a continuous water flow providing a daily exchange of $5 \%$ of the total volume. The areas of the fishponds range between $1501 \mathrm{~m}^{2}(\mathrm{FP} 1)$ and $1850 \mathrm{~m}^{2}$ (FP3), and the mean depth of the ponds is $1.5 \mathrm{~m}$. The source of the water for the ponds is a well, protected by vegetation, located $90 \mathrm{~m}$ from the first fishpond (FP1). The water flows directly into the wetland and then to the fishponds through underground tubes. The macrophyte Typha domingensis is predominant in this shallow wetland (WET), and many animals $\left(0.3 \mathrm{animal} / \mathrm{m}^{2}\right)$, primarily chickens, are present near the ponds.

The fishponds contain species such as pacu (Piaractus mesopotamicus) (FP1 and FP2) and tilapia (Oreochromis niloticus) (FP3) at a density of approximately $1 \mathrm{~kg} / \mathrm{m}^{2}$. The fish are fed a supplementary diet containing $15 \%$ crude protein 2 times daily at $3 \%$ weight per day. After leaving the fishponds, the water passes through a natural soil filter system (SFS) approximately $400 \mathrm{~m}$ long and flows to another farm through underground tubes (Fig. 1). The SFS consists of a natural channel through which the water flows in a long extension structure that can modify the physical and chemical properties of the water.

According to the Köppen classification, the regional climate is Cwa: subtropical, relatively dry in the winter (June to August) and rainy in the summer (December to March), with a mean annual temperature of $22^{\circ} \mathrm{C}$ and a mean annual rainfall of $1552 \mathrm{~mm}$ (Peel et al., 2007).

Samples taken to monitor the abiotic and biotic variables were collected monthly over a 1 year period. The water samples were collected at 7 sampling sites: the inlet water (INW); the wetland (WET); the fishponds (FP1, FP2 and FP3); the soil filter system (SFS); and the outlet water (OUW) (Fig. 1).

\section{Limnological variables}

Samples were collected with a Van Dorn bottle at the surface and transported in refrigerated polyethylene bottles to the laboratory. Nutrient concentrations were measured according to Koroleff (1976) and Golterman et al. (1978). The water temperature, $\mathrm{pH}$ and dissolved oxygen were determined in situ with a multi-parameter meter probe (Horiba U 10, Horiba, Kyoto, Japan).

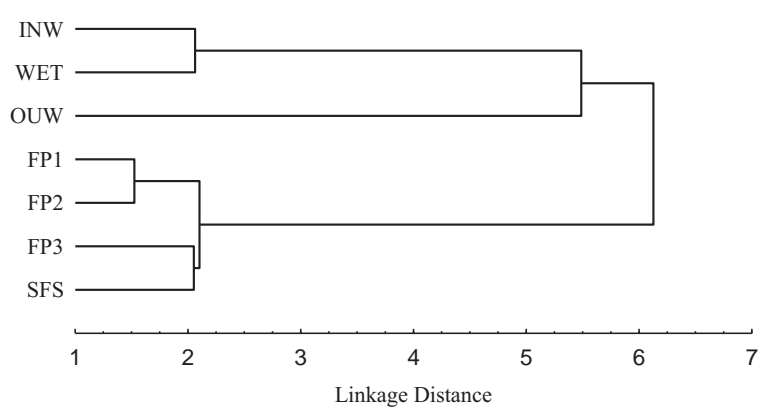

Figure 2. Cluster analysis of the total average densities of plankton and nutrients at the sampling sites in the fee-fishing farm. Abundance data were $\log _{10}(x+1)$ transformed. Análisis de similitud considerando las densidades totales medias de plancton y nutrientes en los sitios de muestreo. Los datos de abundancia fueron transformados a $\log _{10}(\mathrm{x}+1)$. 


\section{Plankton analyses}

To analyse the phytoplankton, $250 \mathrm{ml}$ samples were collected in dark glass containers from the surface of the water at the 7 sites. The samples were fixed with $1 \%$ acid lugol iodine solution. The quantitative phytoplankton samples were placed in a settling chamber for $30 \mathrm{~min}$ utes, and the organisms (cells, colonies and filaments) were counted using a Leica Leitz microscope (APHA, 1998).

Zooplankton samples were collected with a $58 \mu \mathrm{m}$ mesh net at the same sampling sites. The samples were stored in $200 \mathrm{ml}$ polyethylene bottles and fixed with formalin (4\%.v/v final concentration). The mesozooplankton (Copepoda and Cladocera) was counted in acrylic cuvettes under a stereoscopic microscope. The microzooplankton (Rotifera) was counted in a SedgewickRafter chamber under an optical microscope.

\section{Statistical analysis and diversity calculations}

The Shannon-Weaver diversity index $\left(\mathrm{H}^{\prime}\right)$ and richness (total number of species) were used to analyse the diversity of phytoplankton and zooplankton at the study sites during the experiment (Odum \& Barret, 2005).

The sites were grouped with a cluster analysis (unweighted pair group average linkage, UPGMA) using Euclidean distance as the distance measure.
The nutrient data and the $\log _{10}(x+1)$-transformed abundance of all plankton species were used as the descriptor variables (Valentin, 2000).

A Principal Components Analysis (PCA) was used to reduce the dimensionality of the environmental variables and to rank the sites in relation to the characteristics of the water samples collected at the fee-fishing farm (Legendre \& Legendre, 1998). Statistica 7.0 was used for these analyses.

\section{RESULTS}

A similarity analysis for plankton densities and nutrients identified 4 site groups: 1-INW and WET, 2-FP1 and FP2, 3-FP3 and SFS and 4-OUW. The outlet site differed markedly from the other sites in terms of phytoplankton, zooplankton, total phosphorus, nitrate, nitrite, ammonia and orthophosphate (Table 1, Figs. 2 and 3).

The first factorial plane, consisting of axes 1 and 2 of the Principal Components Analysis (PCA), explains up to $70.7 \%$ of the initial variability of the data. On the first axis, INW and WET were located on the negative side and were associated with the highest nitrate and nitrite concentrations as well as with Cyanobacteria, Bacillariophyceae and Zygnemaphyceae. FP2 and FP3 were related to the positive side of axis 1 and to the highest values of temperature (Temp), dissolved oxygen (DO), $\mathrm{pH}$ and Chl-a and were as-

Table 1. Mean values and standard deviations for nitrite $\left(\mathrm{NO}_{2}\right)$, nitrate $\left(\mathrm{NO}_{3}\right)$, ammonia $\left.(\mathrm{NH})_{4}\right)$, orthophosphate $(\mathrm{OP})$, total phosphorus (P), temperature (Temp.), dissolved oxygen (DO) and $\mathrm{pH}$ in the fee-fishing farm samples. INW = inlet water; WET = wetland; FP1, FP2 and FP3 = fishponds; SFS = soil filter system; OUW = outlet water. Valores medios y desviación estándar de nitrito $\left(\mathrm{NO}_{2}\right)$, nitrato $\left(\mathrm{NO}_{3}\right)$, amonio $\left(\mathrm{NH}_{4}\right)$, ortofosfato $(\mathrm{OP})$, fósforo total $(\mathrm{P})$, temperatura (Temp.), oxígeno disuelto $(\mathrm{DO})$ y $\mathrm{pH}$ en el sistema. $I N W=$ entrada de agua, WET = Humedal, FP1-3 = estanques de peces, $S F S=$ sistema de filtración, OUW = salida de agua.

\begin{tabular}{|c|c|c|c|c|c|c|c|}
\hline \multirow{2}{*}{ Variables } & \multicolumn{7}{|c|}{ Sites } \\
\hline & INW & WET & FP1 & FP2 & FP3 & SFS & OUW \\
\hline $\mathrm{NO}_{2}(\mu \mathrm{g} / \mathrm{L})$ & $5.0 \pm 3.7$ & $1.5 \pm 1.4$ & $0.8 \pm 0.9$ & $1.5 \pm 1.4$ & $1.0 \pm 1.3$ & $4.9 \pm 6.9$ & $3.1 \pm 2.2$ \\
\hline $\mathrm{NO}_{3}(\mu \mathrm{g} / \mathrm{L})$ & $247.1 \pm 300.6$ & $25.0 \pm 25.4$ & $9.4 \pm 11.0$ & $9.8 \pm 11.3$ & $16.6 \pm 16.6$ & $54.3 \pm 39.3$ & $8.5 \pm 10.7$ \\
\hline $\mathrm{NH}_{4}(\mu \mathrm{g} / \mathrm{L})$ & $80.4 \pm 71.7$ & $106.1 \pm 63.2$ & $13.1 \pm 21.4$ & $33.1 \pm 62.7$ & $41.8 \pm 60.4$ & $287.6 \pm 227.4$ & $31.2 \pm 17.0$ \\
\hline $\mathrm{OP}(\mu \mathrm{g} / \mathrm{L})$ & $4.6 \pm 5.6$ & $2.7 \pm 4.5$ & $2.8 \pm 2.6$ & $3.5 \pm 3.3$ & $7.5 \pm 3.8$ & $3.9 \pm 5.4$ & $3.8 \pm 5.2$ \\
\hline $\mathrm{P}(\mu \mathrm{g} / \mathrm{L})$ & $35.0 \pm 15.9$ & $32.4 \pm 17.2$ & $38.0 \pm 16.0$ & $40.9 \pm 20.1$ & $44.6 \pm 20.9$ & $37.9 \pm 19.9$ & $10.2 \pm 8.2$ \\
\hline Temp. $\left({ }^{\circ} \mathrm{C}\right)$ & $23.6 \pm 1.6$ & $22.4 \pm 3.1$ & $23.6 \pm 3.2$ & $24.2 \pm 3.6$ & $24.4 \pm 3.6$ & $24.0 \pm 2.5$ & $23.1 \pm 2.0$ \\
\hline DO (mg/L) & $2.4 \pm 2.2$ & $1.8 \pm 0.8$ & $3.5 \pm 1.3$ & $5.0 \pm 1.3$ & $5.4 \pm 1.3$ & $5.1 \pm 1.6$ & $4.3 \pm 2.0$ \\
\hline $\mathrm{pH}$ & $5.7 \pm 0.6$ & $5.8 \pm 0.3$ & $6.1 \pm 0.2$ & $6.5 \pm 0.3$ & $6.7 \pm 0.7$ & $6.5 \pm 0.2$ & $7.1 \pm 0.3$ \\
\hline
\end{tabular}


sociated with high levels of Chlorophyceae and all zooplankton taxa. In contrast, FP1 was not associated with any physical, chemical or biological parameters, although it was similar in size and depth to FP2 and FP3 (Table 1, Fig. 3).

OUW was positioned on the negative side of axis 2 and showed characteristics that were not associated with any particular physical and chemical variable included in the analysis. These characteristics were low nutrient concentrations and a low plankton density. The position of OUW in the biplot graph confirms that the soil filter system effectively modified the biological, physical and chemical parameters of the water. In contrast, SFS is located on the opposite side of axis 2, with high concentrations of ammonia $\left(\mathrm{NH}_{4}\right)$, total phosphorus (P) and orthophosphate (OP), and was related to the zooplankton community. FP1 was positioned in the central region of the principal component analysis and represented an intermediate set of conditions (Table 1, Fig. 3).
The richness of phytoplankton species ranged from 18 (OUW) to 38 (FP2); zooplankton species richness ranged from 7 (OUW) to 29 (WET). Lower planktonic species richness and diversity $\left(\mathrm{H}^{\prime}\right)$ were observed at OUW than at the other sites (Fig. 4). The phytoplankton community included up to 38 taxa during the study period. The Chlorophyceae were the most representative, followed by the Bacillariophyceae, Cyanobacteria, Zygnemaphyceae, Euglenophyceae, Oedogoniophyceae, Dinophyceae and Chrysophyceae. The three last-named groups were each represented by only one species, namely, Oedogonium sp., Sphaerodinium sp. and Dinobryon elegantissimum, respectively. The Chlorophyceae had the greatest relative abundance at sites FP1, FP2 and FP3, especially from November to March, ranging from $10 \%$ to $90 \%$. INW and WET had a relatively high abundance of Zygnemaphyceae $(\geq 60 \%)$ and Bacillariophyceae $(\geq 35 \%)$. SFS and OUW had the highest representation of Oedo-

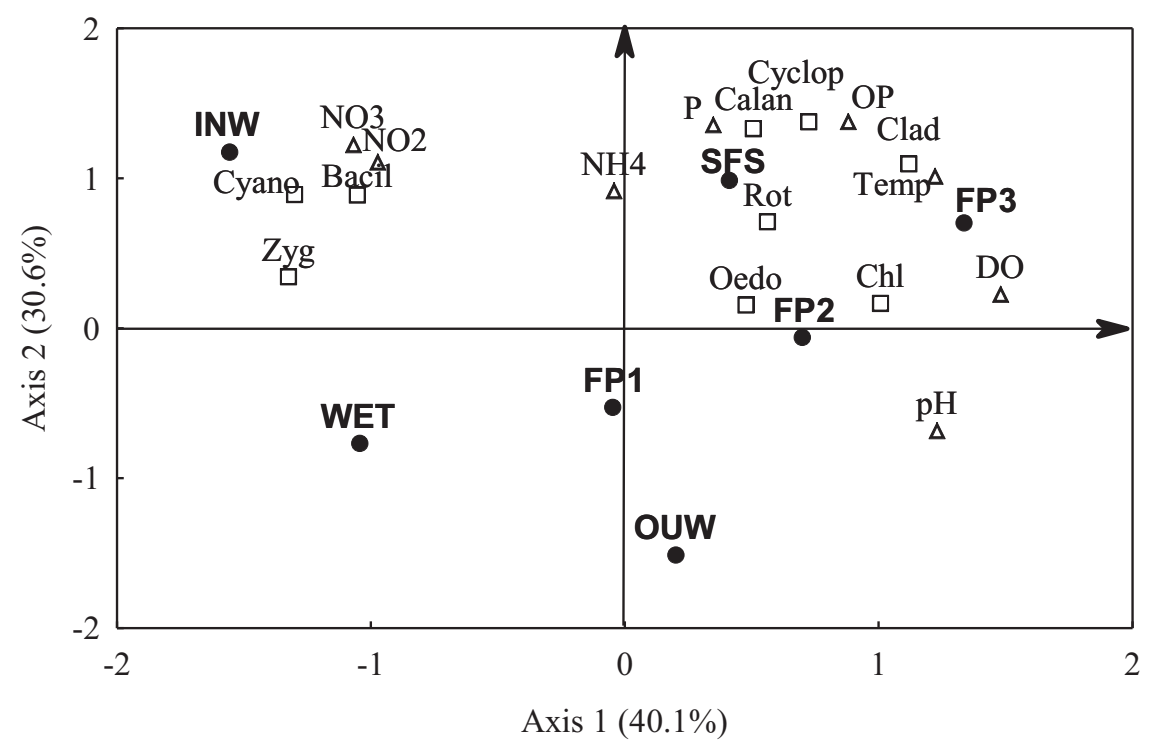

Figure 3. Results of the principal component analysis (PCA). INW = inlet water; WET = wetland; FP1, FP2 and FP3 = fishponds; SFS = soil filter system; OUW = outlet water; circles = sample sites; squares = biotic variables $($ Cyano = Cyanobacteria, Bacil = Bacillariophyceae, Oedo = Oedogoniophyceae, Zyg = Zygnemaphyceae, $\mathrm{Chl}=$ Chlorophyceae, Calan = Calanoida, Cyclop = Cyclopoida, Clad $=$ Cladocera, Rot $=$ Rotifera $)$; triangles $=$ abiotic variables $(\mathrm{NO} 2=$ nitrite, $\mathrm{NO} 3=$ nitrate, $\mathrm{NH} 4=$ ammonia, $\mathrm{P}=$ phosphorus, $\mathrm{OP}=$ orthophosphate, $\mathrm{DO}=$ dissolved oxygen, Temp $=$ temperature). Resultados del análisis de componentes principales $(A C P) . I N W=$ entrada de agua, WET = Humedal, FP1-3 = estanques de peces, SFS = sistema de filtración, OUW = salida de agua $;$ círculo = sitios de muestreo, cuadrados = variables bióticas $($ Cyano = Cyanobacterias, Bacil = Bacillariophyceae, Oedo $=$ Oedogoniophyceae, Zyg = Zygnemaphyceae, $C h l=$ Chlorophyceae, Calan = Calanoida, Cyclop = Cyclopoida, Clad = Cladocera, Rot $=$ rotíferos $) ;$ triángulos $=$ variables abióticas $(N O 2=$ nitrito, $N O 3=$ nitrato, $N H 4=$ amoníaco, $P=$ fósforo, OP = ortofosfato, DO = oxígeno disuelto, Temp = temperatura). 


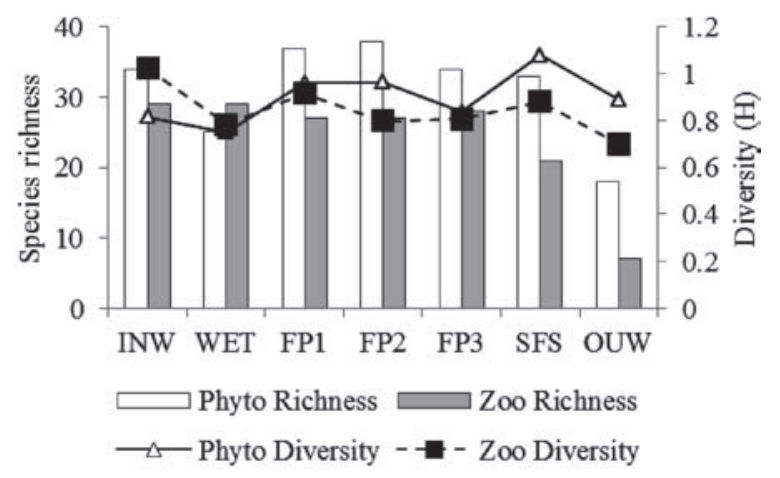

Figure 4. Ecological indices (richness and diversity) of plankton communities at the study sites during the study period. $\mathrm{INW}=$ inlet water; WET $=$ wetland; FP1, FP2 and FP3 = fishponds; SFS = soil filter system; OUW = outlet water. Índices ecológicos (riqueza y diversidad) de las comunidades planctónicas en los puntos de muestreo durante el período estudiado. $I N W=$ entrada de agua, WET = humedal, FP1-3 = estanques de peces, SFS = filtro de suelo, OUW = salida de agua.

goniophyceae, ranging from $10 \%$ to $70 \%$. Compared with the other sites, OUW had the lowest relative abundance of Cyanobacteria $(<5 \%)$ (Fig. 5).

Zooplankton species richness was lower than that of phytoplankton except at the WET site. Overall, the zooplankton community consisted of 38 taxa: 31 Rotifera, 5 Cladocera and 2 Copepoda. Rotifer species were present at a constant level at all sampled sites, and this group showed the highest relative abundance $(\geq 85 \%)$. Cyclopoid copepods were common at SFS, ranging from $3 \%$ to $16 \%$. Conversely, Calanoid copepods had a low representation at the sites associated with the water supply (INW and WET) but increased from FP1 to FP3, ranging from $5 \%$ to $80 \%$. Cladocera had the highest relative abundance at OUW in January (100\%) and February (80 \%) (Fig. 6).

\section{DISCUSSION}

The animals in the area of the WET site influenced the diversity of plankton and the water quality at the fee-fishing farm. The presence of domestic animals (cattle, horses and chickens) near the WET site increased the nutrient content and favoured Cyanobacteria and Bacillariophyceae due to the shallow water, the displace-
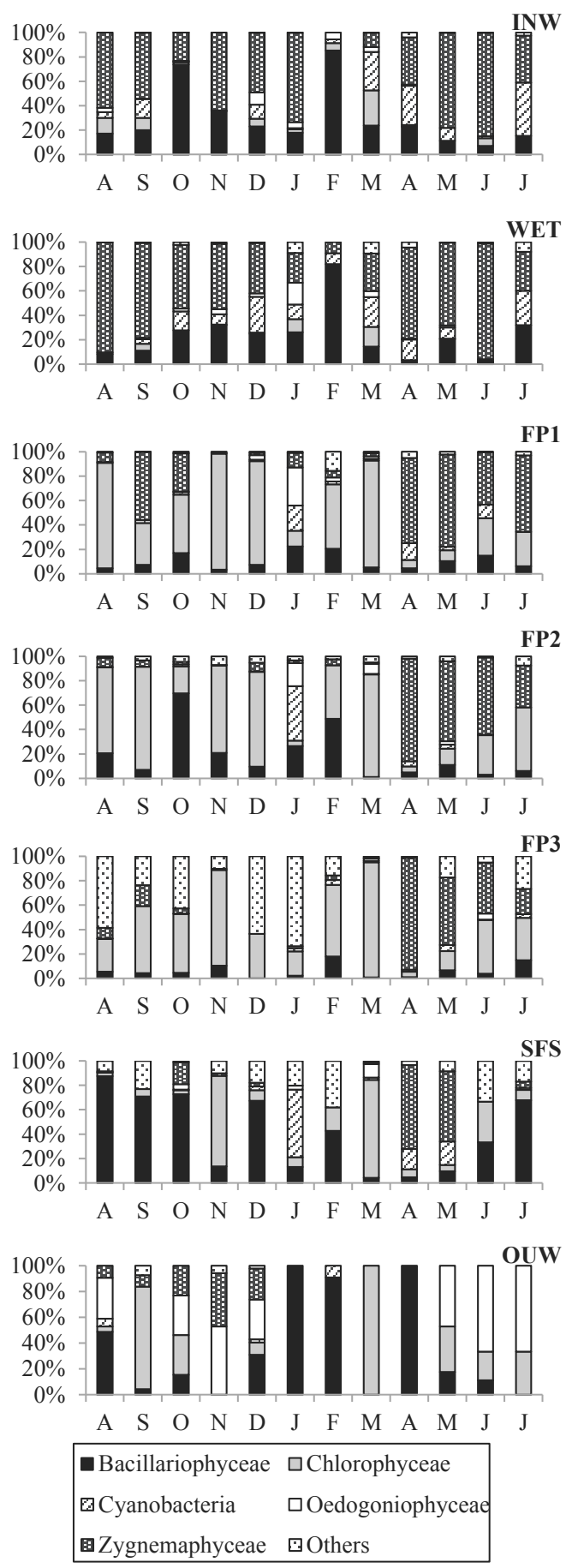

Figure 5. Relative abundance of phytoplankton groups based on cell abundance at the sampling sites during the study period; others = Dinophyceae + Euglenophyceae + Chrysophyceae . Abundancia relativa de los grupos de fitoplancton basada en la abundancia de células en los puntos de muestreo durante el período estudiado; otros = Dinophyceae + Euglenophyceae + Chrysophyceae. 
ment of sediment to the water column and the decrease in light penetration. As a result, the presence of domestic animals affected the abundance and diversity of phytoplankton and zooplankton. Bacillariophyceae, which require low light levels for their development, were favoured at WET.

Habitat structure is one of the fundamental factors determining the distribution of organisms on all spatial scales, and vegetation is of primary importance in shaping the structural environment for invertebrates in many systems, contributing to an increase in the biodiversity of the environment in question. The structural complexity of aquatic vegetation most likely provides a wide variety of potential refuges from predators for both Rotifera and Crustacea (Kuczýnska-Kippen \& Swidnicki, 2008). For this reason, these groups of animals showed a higher richness at WET, which was dominated by the macrophyte Typha domingensis. This macrophyte could act as a green filter to reduce the nutrient load reaching the fee-fishing farm if the above-ground biomass is harvested when it contains the maximum amounts of nutrients (Eid et al., 2012). The green filter would assimilate part of the nutrient load produced by the animals in the area of the farm.

A constant level of Cyanobacteria was found in the supply water (INW and WET) and at SFS due to the relatively high nutrient loads received by these sites. The PCA showed that Cyanobacteria was related to INW and WET and associated with the presence of the animals in the area. The animals excrete organic nitrogen to the water, promoting higher concentrations of nitrogen forms and providing adequate conditions for phytoplankton growth (Ye et al., 2012).

The water flowing directly from WET to FP1 showed the influence of the nutrients originating from the domestic animals in the area of WET. The higher richness of phytoplankton in FP1 and FP2 showed a relatively strong association with the dominant fish species, the pacu (Piaractus mesopotamicus) because this species is omnivorous in the adult stage, feeding primarily on fruit, seed, grain, small molluscs, crustaceans and insects (Sipaúba-Tavares \& Braga, 1999). The species richness of phytoplankton decreased in FP3, most likely due to grazing by tilapia (Ore- ochromis niloticus), a herbivorous fish capable of feeding on phytoplankton (Getachew, 2006).
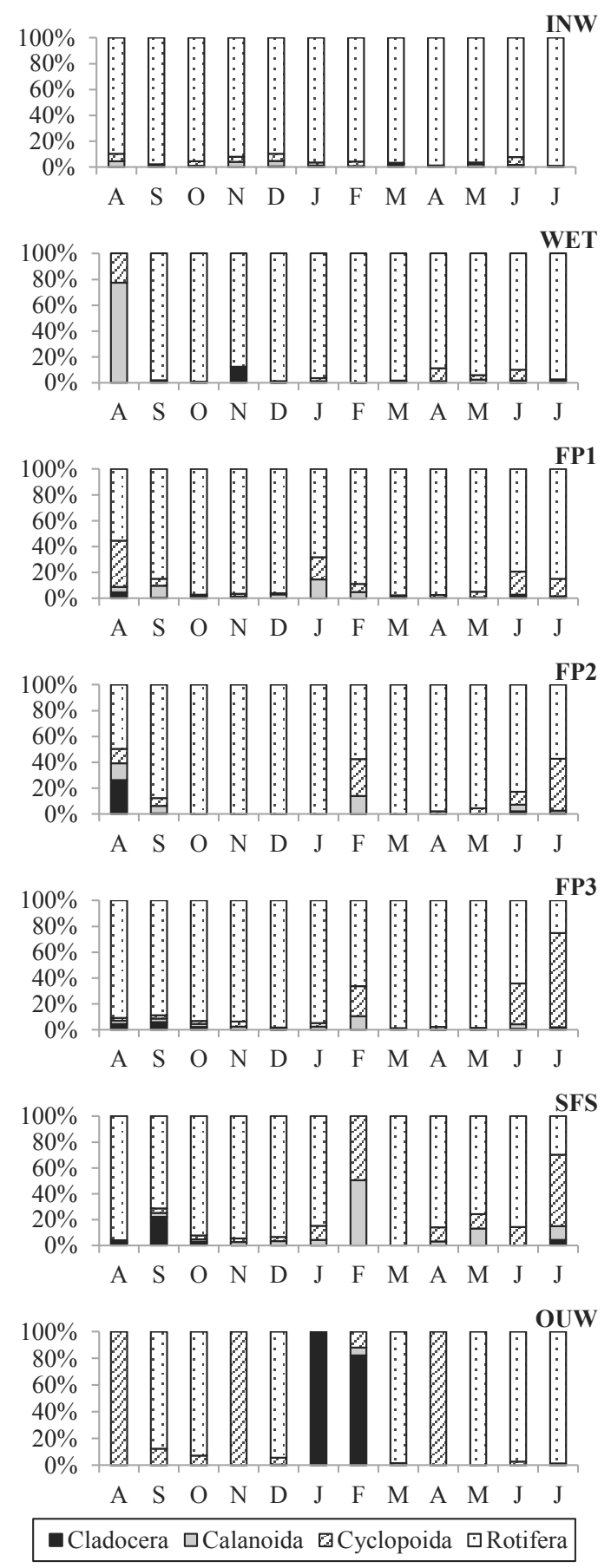

Figure 6. Relative abundance of zooplankton groups at the sampling sites during the study period. Abundancia relativa de los grupos de zooplancton en los puntos muestreados durante el período de estudio. 
As in other ponds in this region, Chlorophyceae (Sipaúba-Tavares et al., 2006; Lachi \& Sipaúba-Tavares, 2008) were dominant in the fish ponds (FP1, FP2 and FP3). Chlorophyceae can be an important food for fish, especially tilapia (Abdel-Tawwab \& El-Marakby, 2004). The relative abundance of Chrysophyceae was significantly higher in FP3 than in the other ponds during the study period and was accompanied by lower abundances of Zygnemaphyceae and Cyanobacteria. This finding may be explained by the presence of tilapia because small organisms with rigid cell walls, such as these algae, are resistant to tilapia predation.

Rotifera had the highest richness and greatest abundance of all zooplankton groups during the study period. Sequential layout and continuous water flow are characteristics that favour the dynamics of these organisms in fishponds (Macedo \& Sipaúba-Tavares, 2005). In fact, small-sized organisms are characterized as $r$-strategists and opportunists, with a short life cycle and a broad tolerance to environmental disturbances (Neves et al., 2003).

The decrease in plankton community diversity $\left(\mathrm{H}^{\prime}\right)$ from SFS to OUW may have been caused by the strong current flowing through the soil filter system. The soil filter system decreases the amount of nutrients available to the plankton community, positively affecting the water from the fee-fishing farm. In the soil filter system, filtration, sedimentation, adsorption, inactivation and microbial metabolism are the mechanisms that decrease several abiotic water parameters (Boutilier et al., 2009).

The water supply showed low quantities of phosphorus and orthophosphate. This finding indicates the importance of treating the water before it enters the fishponds. The decrease in nutrients resulting from water treatment could be unfavourable for the plankton community. However, the fishponds must receive water of adequate quality in sequence, as each fishpond directly or indirectly receives water from WET. The sources of phosphorus at the fee-fishing farm are excretion by fish and fish feed, and water quality can be affected by these factors. The soil filter system (approximately $400 \mathrm{~m}$ in length) at the fee-fishing farm was efficient in decreasing the nutrient load. As a result, OUW showed significant differences from the other sites and was found to have a low nutrient load and low plankton density.

The results of the study demonstrated that plankton communities and abiotic parameters were affected by the continuous water flow through the fee-fishing farm and by animals in the area of the farm. Accordingly, it is advisable to keep animals away from the fishponds. The soil filter system at the lower end of the feefishing farm positively affected the water quality and the plankton communities. This finding indicates that such a soil filter system can prove to be an important tool in aquaculture. However, we would strongly argue that more work is needed to raise the awareness of these issues as they relate to fee-fishing farms. As part of this process, there is an urgent need to transmit correct technology to improve fee-fishing ponds and to advise the anglers and farmers about the value of the maintenance of suitable water quality.

\section{ACKNOWLEDGEMENTS}

The authors would like to thank FAPESP for a scholarship provided (05/56870-7) to the first author and CNPq (131061/2007-0) for financial support.

\section{REFERENCES}

ABDEL-TAWWAB, M. \& H. I. EL-MARAKBY. 2004. Length-weight relationship, natural food and feeding selectivity of Nile tilapia Oreochromis niloticus (L.) in fertilized earthen ponds. In: The $6^{\text {th }}$ International Symposium of Tilapia in Aquaculture. R. Bolivar, G. Mair \& K. Fitzsimmons (ed.): 500-509. Philippine International Convention Center, Roxas Boulevard, Manila, Philippines.

ANTÓN-PARDO, M. \& X. ARMENGOL. 2010. Zooplankton community from restored peridunal ponds in the Mediterranean region (L'Albufera Natural Park, Valencia, Spain). Limnetica, 29 (1): 133-144. 
APHA-AWWA-WEF. 1998. Standard Methods for the Examination of Water and Wastewater, $20^{\text {th }}$ Ed. Public Health Association. NY. USA. 1031 pp.

BOUTILIER, L. JAMIESON, R., GORDON, R., LAKE, C. \& HART, H. 2009. Adsorption, sedimentation, and inactivation of E. coli within wastewater treatment wetlands. Water Research, 43 (17): 4370-4380.

DIAS, J. D., N. R. SIMÕES \& C. C. BONECKER. 2012. Zooplankton community resilience and aquatic environmental stability on aquaculture practices: a study using net cages. Brazilian Journal of Biology, 72 (1): 1-11.

EID, E. M., K. M. SHALTOUT, M. A. EL-SHEIKH \& T. ASAEDA. 2012. Seasonal courses of nutrients and heavy metals in water, sediment and above- and below-ground Typha domingensis biomass in Lake Burullus (Egypt): perspectives for phytoremediation. Flora, 207 (11): 783-794.

GETACHEW, T. 2006. A study on an herbivorous fish, Oreochromis niloticus L., diet and its quality in two Ethiopian Rift Valley lakes, Awasa and Zwai. Journal of Fish Biology, 30 (4): 439-449.

GOLTERMAN, H. L., R. S. CLYMO \& M. A. M. OHMSTAD. 1978. Methods for physical and chemical analysis of freshwaters. Blackwell Scientific Publications. Oxford. 214 pp.

KARJALAINEM, H., S. SEPPALA \& M. WALLS. 1998. Nitrogen, phosphorus and Daphnia grazing in controlling phytoplankton biomass and composition -an experimental study. Hydrobiologia, 363: 309-321.

KOROLEFF, F. 1976. Determination of nutrients. In: Methods of seawater analysis. E. Grashof \& E. Kremling. (ed): 117-181.Verlag Chemie Wenhein, New York.

KUCZÝNSKA-KIPPEN, N., K. SWIDNICKI. 2008. The spatial structure of zooplankton communities and trophic state of mid-city Strzeszynskie lake. Teka Komisji Ochrony I Kształtowania Środowiska Przyrodniczego, 5: 85-94.

LACHI, G. B. \& L. H. SIPAÚBA-TAVARES. 2008. Qualidade da água e composição fitoplanctônica de um viveiro de piscicultura utilizado para fins de pesca esportiva e irrigação. Boletim do Instituto de Pesca, 34 (1): 29-38.

LEGENDRE, P. \& L. LEGENDRE. 1998. Numerical Ecology. Elsevier Science B.V., Amsterdam. $853 \mathrm{pp}$.

MACEDO, C. F. \& L. H. SIPAÚBA-TAVARES. 2005. Comunidade planctônica em viveiros de criação de peixes, em disposição sequencial. Boletim do Instituto de Pesca, 31: 21-27.

MATSUZAKI, M., J. L. N. MUCCI \& A. A. ROCHA. 2004. Phytoplankton community in a recreational fishing lake, Brazil. Revista de Saúde Pública, 38 (5): 679-686.

NEVES, I. F., O. ROCHA, K. F. ROCHE \& A. A. PINTO. 2003. Zooplankton community structure of two marginal lakes of the River Cuiabá (Mato Grosso, Brazil) with analisys of rotifera and cladocera diversity. Brazilian Journal of Biology, 63 (2): 329-343.

ODUM, E. P. \& G. W. BARRETT. 2005. Fundamentals of Ecology. Thomson Brooks/Cole. USA. $624 \mathrm{pp}$.

PEEL, M. C., B. L. FINLAYSON, T. A. MCMAHON. 2007. Updated world map of the Köppen-Geizer climate classification. Hydrobiology and Earth System Sciences, 11: 1633-1644.

POKORNÝ, J. \& V. HAUSER, V. 2002. The restoration of fish ponds in agricultural landscapes. Ecological Engineering, 18: 555-574.

RAHMATI, R., R. POURGHOLAM, S. H. NAJAFPOUR \& M. DOUSTDAR. 2011. Trophic status of a shallow lake (north of Iran) based on the water quality and the phytoplankton community. World Applied Sciences Journal, 14: 112-120.

SCHUETT, M. A. \& C. D. PIERSKALLA. 2007. Managing for desired experiences and site preferences: the case of fee-fishing anglers. Environmental Management, 39: 164-177.

SIPAÚBA-TAVARES, L. H. \& F. M. S. BRAGA. 1999. Study on feeding habits of Piaractus mesopotamicus (Pacu) larvae in fish ponds. Naga, The ICLARM Quarterly, 22 (1): 24-29.

SIPAÚBA-TAVARES, L. H., BACCARIN, A. E. \& F. M. S. BRAGA. 2006. Limnological parameters and plankton community responses in Nile tilapia ponds under chicken dung and NPK (4-14-8) fertilizers. Acta Limnologica Brasiliensia, 18 (3): 335346.

SIPAÚBA-TAVARES, L. H., E. M. LOURENÇO, \& F. M. S. BRAGA. 2010. Water quality in six sequentially disposed fishponds with continuous water flow. Acta Scientiarum Biological Sciences, 32 (1): 9-15.

SSANYU, G. A., J. RASOWO, E. AUMA \& NDUNGURU. 2011. Evaluation of plankton community structure in fish refugia action as Oreochromis niloticus propagation and nursery units for rice/ 
fish trials, Uganda. Journal of Aquaculture Research and Development, 2 (4): 1-6.

VALENTIN, J. L. 2000. Numerical Ecology: an introduction to multivariated analysis of ecological. Interciência. 117 p. (in Portuguese)
YE, L., X. SHI, X. WU \& F. KONG. 2012. Nitrate limitation and accumulation of dissolved organic carbon during a spring-summer cyanobacterial bloom in Lake Taihu (China). Journal of Limnology, 71 (1): 67-71. 